\title{
MESTSKÉ DIVADLO V PREŠPORKU V KONTEXTE VÝVOJA MESTSKÝCH DIVADIEL V STREDNEJ EURÓPE V DRUHEJ POLOVICI 19. STOROČIA
}

\author{
JANA L A S L AV Í K O V Á
}

\begin{abstract}
LASLAVÍKOVÁ, Jana. The city theatre in Pressburg in the context of the development of city theatres in Central Europe in the second half of the 19th century. Historický časopis, 2019, 67, 2, pp. 241-263, Bratislava.

The study considers the origin of the City Theatre in Pressburg at the end of the 19th century in relation to the cultural history of the city. The circumstances of the building of a new theatre by the well-known pair of architects Ferdinand Fellner jun. and Hermann Gottfried Helmer demonstrate the political and social situation in the city, which wanted to maintain a German character, while also satisfying the demand for Hungarian theatre from Hungarian members of elite urban societies. Thus, the building of the new theatre was closely connected with an effort to renew the cultural memory of the city and present its rich past using new media of cultural transfer, but it was also an instrument for the promotion of political interests.
\end{abstract}

Key words: City theatres in 19th century Europe. Ferdinand Fellner jun. and Hermann Gottfried Helmer. The project to build a new city theatre in Pressburg. Ceremonial opening.

DOI: https://doi.org/10.31577/histcaso.2019.67.2.3

História Mestského divadla v Prešporku (dnešnej Historickej budovy Slovenského národného divadla $v$ Bratislave) sa začala písat' 7. júla 1884, ked' municipálny výbor vypočul žiadosti Prešporčanov a na základe odporúčania uhorskej vlády definitívne rozhodol o postavení novej divadelnej budovy. Budovu dokončili v roku 1886 a jej slávnostné otvorenie sa konalo 22. septembra 1886 za účasti predstavitel'ov kultúrneho, spoločenského a politického života $\mathrm{z}$ domáceho prostredia, hostí z Budapešti, Viedne, ako aj d'alších okolitých miest. Divadlo patrilo mestu, ktoré ho prenajímalo divadelným riaditel’om uvádzajúcim predstavenia v nemeckom a mad'arskom jazyku. Tento spôsob prevádzky sa uplatňoval až do roku 1920, ked' pod vplyvom politických udalostí došlo k inštitucionálnej zmene a v divadle sa začali konat' pravidelné predstavenia českých a slovenských umelcov pod záštitou novovzniknutého Družstva SND.

Postavením Mestského divadla v Prešporku sa otvorila nová kapitola v kultúrnej histórii mesta, ktorú spoluvytvárali životné osudy umelcov účinkujúcich 
v Prešporku na sklonku 19. storočia. Dramatické umenie získalo v novej budove nielen nový domov, ale niečo viacej - nový status a spolu s ním aj poslanie. Vel'ký dopad na divadelnú prevádzku malo rakúsko-uhorské vyrovnanie z roku 1867, ked’že divadlo bolo centrom spoločenského života a slúžilo na reprezentáciu mestských elít. Nové divadlo malo byt' miestom pestovania mad'arskej kultúry, avšak vzhl'adom na prevahu obyvatel'ov hovoriacich po nemecky v čase postavenia novej budovy bolo zjavné, že výlučne mad'arské predstavenia by boli finančne nerentabilné. Súčasne s ohl'adom na kultúrne preferencie stáleho publika, ovplyvnené viedenských umeleckým prostredím, sa municipálnemu výboru javilo ako neprijatel'né. Preto sa mesto dohodlo na striedaní sa nemeckých a mad'arských divadelných predstavení $\mathrm{v}$ Mestskom divadle, pričom toto riešenie bolo prezentované ako dočasné.

Divadlá v 19. storočí boli vnímané ako centrálne umelecké inštitúcie s kultúrnou, spoločenskou a politickou funkciou. Divadelný priestor odjakživa znamenal priestor plný myšlienok, príbehov a ideí, ktoré boli komunikované publiku. Vzt'ah medzi umelcom a divákom podmieňoval nielen divadelný obsah, ale aj divadelná forma, samotná divadelná budova, ktorá odzrkadl'ovala kultúrne, sociálne a technické aspekty doby. Nebolo tomu inak ani v prípade Prešporka. Projekt popredných divadelných architektov Ferdinanda Fellnera ml. a Hermanna Helmera zmenil tvár mesta a prispel k reprezentácii a prestízi Prešporka a jeho obyvatel’ov v rámci monarchie. ${ }^{1}$ Ked’že išlo o jeden z prvých projektov po zavedení nových bezpečnostných predpisov v rámci divadelných stavieb, prezentoval výsledky ich aplikovania zo strany viedenskej architektonickej dvojice a bol východiskom pre d’alšie stavby.

\section{Mestské divadlá v 19. storočí v strednej Európe}

„Dlhéc" 19. storočie označované za obdobie industrializácie, nových vynálezov a rýchlych zmien zdanlivo ukončilo kontinuitu odklonom od tradície a vyznávaním dvojitej morálky. Zmeny vo vrstvení spoločnosti priniesli vznik nových elít, ktoré si paradoxne žiadali renesanciu historických slohov v podobe historizmu ako umeleckého štýlu v architektúre. Špecifickým znakom tohto obdobia bol vel'ký nárast divadelných stavieb, spôsobený vzostupom sociálnej vrstvy, ktorá bola schopná zaplatit' stavbu novej budovy pre divadlo a prejavovala záujem o umenie a vzdelanie.

Túžba po návrate do minulosti, obracanie sa $\mathrm{k}$ historickým témam $\mathrm{v}$ umení sa premietla aj do divadelnej architektúry. Historizmus ako umelecký štýl meštianstva znamenal spájanie štýlov, návraty do histórie v podobe neogotiky,

1 TRÜMPI, Fritz - MARSCHALL, Brigitte. Between Monarchy and Civil Society. In KOVAČEVIĆ, Igor (ed.). Beyond Everydayness: Theatre Architecture in Central Europe. Praha: Národní divadlo, 2010, s. 33. ISBN 9788072583645. 
neorenesancie, neobaroka, neoklasicizmu, neoromantizmu. Toto rozbitie jadra historických stavieb v istom zmysle odzrkadl'ovalo heterogénnost' v sociálnom a kultúrnom povedomí tejto otvorenej sociálnej skupiny. Za pomoci poznatkov z histórie sa jednotlivé štýly vedome rozlišovali a používali a vyjadrovala sa nimi určitá politicko-ideologická výpoved'. Renesancia ako prejav humanizmu symbolizovala vzdelanie a kultúru, barok zdôrazňoval moc a vážnost'. Tieto dva neoštýly prevažovali v divadelných stavbách 19. storočia.

Divadlá sa stali novodobými chrámami kultúrneho náboženstva meštianstva. Boli symbolom prestízee, sebaprezentácie, modernosti i pokrokovosti a zároveň viditel'nými znakmi nároku na národnú rovnost', resp. hegemóniu. Pomocou politického a spoločenského vývoja sa zároveň stali médiom kolektívnej identity a identifikačnej politiky. Vd’aka svojej národnej symbolike, prítomnej v príhovoroch a novinových správach pri príležitosti otvorenia nového divadla za účasti množstva l'udí, sa divadlo menilo na miesto pamäti so silným národným významom. ${ }^{2}$ Táto úloha sa premietla aj do diskusií o kultúrnopolitickej úlohe divadla, konajúcich sa počas významných predstavení, jubileí, osláv či škandálov a konfliktov, ktoré sa v divadle stali. Nešlo preto len o uvádzané diela, divadlo predstavovalo kultivovanú reprezentáciu mesta a v diskusiách a debatách o mestskom divadle, jeho úlohe a postavení sa stávalo nástrojom kolektívnej identity.

Snaha meštianskej vrstvy približit' sa úrovni vzdelania šl'achty sa popri podpore vysokoškolského štúdia $\mathrm{v}$ rodinách prejavila častou návštevou divadla. Ako najžiadanejší druh sa ukazovala opera. Svojou vel'kolepou výpravou a svojím barokovým dvorným pôvodom spíňala túžbu meštianstva po honosnej prezentácii. Obecenstvo volalo po nových obsahoch v divadle. Historické námety sa prepájali so vzt’ahom k životnej skúsenosti publika. Prežívanie cudzej drámy publikum vnímalo ako ozvláštnenie vlastného každodenného života, pričom až do uvádzania novodobej drámy a hier so sociálnym obsahom neprišlo k zmiešaniu sa divadla a reality. ${ }^{3}$ Dôraz na morálku a bezúhonné chovanie sa postáv v uvádzaných dielach stáli v protiklade s morálkou obecenstva, ktorého dvojitý život sa neraz stal námetom činoherných a hudobnodramatických diel. Bohaté

2 UHL, Heidemarie. Das Theater als Gedächtnisort. Das Grazer Stadttheater - ein Medium kultureller Identität im sozialen Raum. In DIENES, Gerhard Michael (ed.). Fellner \& Helmer Die Architekten der Illusion : Theaterbau und Bühnenbild in Europa; anlässlich des Jubiläums „,100 Jahre Grazer Oper“. Graz: Stadtmuseum Graz, 1999, s. 113. ISBN 3900764212.

3 K inscenácii meštianstva v opere pozri ZVARA, Vladimír. Hudba a hudobné divadlo v Bratislave pred prvou svetovou vojnou a po nej. Aspekty a súvislosti. In CHALUPKA, Lubomír (ed.). Príspevky k vývoju hudobnej kultúry na Slovensku. Bratislava: Stimul, 2009, s. 75. ISBN 9788089236664 a KOPECKÝ, Jiří - KŘUPKOVÁ, Lenka. Das Olmützer Stadttheater und seine Oper. „Wer in Olmütz gefällt, gefällt der ganzen Welt" Neue wege - nové cesty: Schriftenreihe des Sudetendeutschen Musikinstituts, Band 14. Regensburg: ConBrio Verlagsgesellschaft, 2017, s. 203. ISBN 9783940768728. 
kostýmy a náročná výprava na javisku sa zrkadlili v bohatých róbach a spoločenskom živote $\mathrm{v}$ publiku: divadlo sa stávalo javiskom meštianstva a z divákov sa stávali účinkujúci. Prezentácia v rámci priestorov divadelnej budovy sa stala súčast’ou divadelných večerov. Zároveň bolo divadlo výnimočným miestom a divadelný svet oživoval stereotypný každodenný život.

Divadlo vplývalo na mesto ako estetická inštitúcia a spoločenská komunikačná agentúra, pričom pamät’ mesta možno chápat' ako scenár pamätania, zapamätávania si, pripomínania si niečoho. ${ }^{4}$ Mesto sa tak javí ako budovaný a rastúci priestor, ktorý je podmienený koncentráciou komunikácie, dynamiky, dopravy, neustálej zmeny a vytvára štruktúry, ktoré môžu fungovat’ ako úložisko pamäti. Samostatnou kategóriou sa javí divadelná stavba, ktorá zahltila priestor špecifickou symbolikou s konkrétnym významom pre daný mestský priestor. Architektúra sa dostala do súvisu s komunikáciou, zintenzívnenou technickým pokrokom: vybavenie divadiel v 19. storočí oplývalo technickými výdobytkami, transportujúcimi kultúrnu symboliku do vonkajšieho priestoru. Denníky, fotografia, telegrafia, divadelné i tanečné priestory, to všetko tvorilo novodobé médiá kultúrnej komunikácie. Divadlo tak možno považovat' za médium, ktoré vstúpilo do virtuálneho priestoru médií, a tak sa ono samo stáva „médiom“, ktoré reprodukuje mestský priestor a symbolicky transportuje komunikačné štruktúry. ${ }^{5}$

K médiám mestských priestorov v 19. storočí možno zaradit' aj svetové výstavy, ktoré ako oficiálne vizitky svojej doby, ako zinscenované podoby svetového divadla patrili k verejným spôsobom prezentácie meštianstva. Ukazovali najnovší priemyselný a stavebný vývoj a znovuoživovali dávnu túžbu po ilúzii, čím sa stotožňovali s úlohou divadla v tomto období. Podobnou inscenáciou divadla bola Medzinárodná hudobná a divadelná výstava vo Viedni v roku 1892, ktorá znovuoživila mýtus Alt-Wien: mesta, ktoré žije zo svojej minulosti. ${ }^{6}$ Reprodukcia Horného trhu zo 17. storočia (večer osvetleného moderným elektrickým svetlom) sa stala synonymom „starej Viedne“, ktorá po zvalení mestských hradieb rýchlo menila tvár. Rýchly rast mesta spojený s prudkým prírastkom

4 CSÁKY, Moritz. Das Gedächtnis der Städte. Kulturelle Verflechtungen - Wien und die urbanen Milieus in Zentraleuropa. Wien; Köln; Weimar: Böhlau Verlag, 2010, s. 21. ISBN 9783205785439.

5 BAUER, Marcus. TheaterStadtRaum - Urbane Kommunikationsstrukturen in „Mitteleuropa“. In ZVARA, Vladimír (ed.). Musiktheater in Raum und Zeit. Beiträge zur Geschichte der Theaterpraxis in Mitteleuropa in 19. und 20. Jahrhundert. Bratislava: NM CODE v spolupráci s Asociáciou Corpus, 2015, s. 19. ISBN 9788089484058.

6 WESSELY, Katharina. ... dies „Ragout aus Anderer Schmaus“ Die Neuerfindung des Alt-Wiener Volkstheaters im Rahmen der Internationalen Musik- und Theaterausstellung in Wien 1892. In SOMMER-MATHIS, Andrea - GROSSEGGER, Elisabeth - WESSELY, Katharina (eds.). Spettacolo barocco - Performanz, Translation, Zirkulation. Wien: Hollitzer, 2018, s. 191. ISBN 9783990125069. 
obyvatel'stva vyvolal v živote Viedenčanov rozpor medzi túžbou po pokroku a zidealizovanou predstavou o utiahnutí sa do pokoja rodinného života. Návrat k „starej Viedni“" sa stal vynúteným dôsledkom, ktorý konštituoval obraz Viedne na prelome 19. a 20. storočia a mal dosah na rozšírenie mýtu v rámci celej monarchie. ${ }^{7}$

Syndróm úteku do minulosti či zidealizovaného rodinného života zažívali obyvatelia mnohých európskych vel'komiest. Silnejúca meštianska vrstva súčasne hl’adala možnosti vlastnej prezentácie, ktoré jej ponúkali novovznikajúce mestské divadlá. Fenomén reprezentácie, ktorý viedol k výstavbe mestských divadiel, neznamenal však zánik dvorných a šlachtických divadiel, ktoré mali vd’aka bohatým majitel'om zabezpečenú stabilnú divadelnú prevádzku. Ked' majitel' poveril vedením nadaného intendanta, stali sa tieto divadlá miestami významných umeleckých počinov. Majitel’mi mestských divadiel bývali mestá, ktoré bud' samy viedli jeho réžiu (platilo len v niekol'kých prípadoch bohatších miest), alebo budovu prenajímali divadelným riaditel'om, ktorí sa starali o jeho umeleckú prevádzku. Od mesta dostávali riaditelia bud' finančnú podporu, alebo úl'avy na platbách za režijné náklady. Na umeleckú úroveň predstavení dohliadala divadelná komisia, ktorá brala do úvahy jednak finančný faktor a jednak kultúrno-vzdelávacie poslanie divadla. Mesto malo záujem na dobrom fungovaní divadla, ked’že bolo vizitkou lokálnej kultúry a popri kostole a radnici dôležitým pilierom mestskej kultúry. Primárna funkcia divadla $\mathrm{v}$ meste sa zrkadlila v divadelných stavbách, preto $\mathrm{k}$ najvýznamnejším architektom 19. storočia patrili autori projektov mestských divadiel.

\section{Architekti Fellner a Helmer}

Stavitel'ský rozmach v 19. storočí viedol k špecializácii architektov na divadelné stavby. V druhej polovici 19. storočia prichádza k výrazným technickým a architektonicko-stavebným zmenám. Autor drážd’anských divadiel Gottfried Semper ešte koncom 18. storočia jasne vytýčil nový štýl exteriéru, ktorý odzrkadl'oval vnútornú funkciu stavby: každému bolo na prvý pohl'ad jasné, že budova slúži divadlu. Začal sa používat' typ podlhovastej poloválcovito ukončenej budovy, ktorý u Sempera slúžil ako architektonický estetický prvok. Od roku 1880, ked' prišlo k zavádzaniu nových požiarno-bezpečnostných opatrení, zostalo vonkaj-

7 Výstava bola chápaná ako „,výstavná skriňa kultúry multietnickej monarchie“ a denne ju navštevovalo tisíce l'udí zblízka aj zd’aleka. Pre potreby divadla postavila viedenská kancelária Fellner a Helmer divadlo v Prátri, ktoré sa stalo svedkom premiéry českej národnej opery Prodaná nevěsta. Ďalej boli uvedené opery Pietra Mascagniho a Ruggiera Leoncavalla, ktoré sa po vel'kom úspechu vo Viedni rozš́rili do celej Európy. Viacej pozri SOMMER, Monika - UHL, Heidemarie (eds.). Mythos Alt-Wien. Spannugsfelder urbaner Identitäten. Innsbruck; Wien; Bozen: Studienverlag, 2009. ISBN 9783706543866. 
šie členenie budovy poznávacím znakom divadiel, ale zároveň slúžilo ako ochrana pred vel'kými požiarnymi katastrofami, typickými pre 19. storočie.

$\mathrm{K}$ najväčším a najznámejším divadelným architektom pôsobiacim na území niekdajšej rakúsko-uhorskej monarchie patrili Ferdinand Fellner ml. (1847, Viedeň - 1916, Viedeň) a Hermann Gottfried Helmer (1849, Harburg-dnes čast' Hamburgu - 1919, Viedeň). Svojimi stavbami vytvorili vlastnú topografiu strednej Európy. Boli autormi takmer pät'desiatich divadiel od Hamburgu cez Zürich po Odesu a medzi ich projekty patrilo aj nové Mestské divadlo v Prešporku. Možno povedat', že vd'aka nim vznikol imaginatívny svet, v ktorom si mestá mohli vylepšit’ svoj vzhl'ad prostredníctvom divadelných budov značky „Fellner \& Helmer", kde vznikol virtuálny priestor, ktorý v umeleckej rovine vyzdvihoval popri všetkých rozdieloch to spoločné: strednú Európu. Pri pohl'ade na rozsiahly zoznam zrealizovaných stavieb $\mathrm{v}$ časovo náročných termínoch by sa zdalo, že jedna stavba kopírovala d'alšiu. ${ }^{8}$ Avšak pri detailnejšom pohl'ade na architektonickú prácu možno pozorovat' rozdiely, ktoré súviseli s kapacitou divadla, urbanistickým usporiadaním mesta, spoločensko-politickou situáciou a finančnými prostriedkami objednávatel'a. ${ }^{9}$

Spoločná kancelária architektov Fellner a Helmer neprojektovala len divadelné projekty, ${ }^{10}$ avšak tie stáli v popredí činnosti a kvôli nízkej cene boli bezkonkurenčné (projekty sa nazývali „Architektur von der Stange“). Pri pohl'ade na zoznam realizovaných projektov je zrejmá vel'ká rozmanitost' miest, v ktorých vznikali divadlá z tejto kancelárie. Išlo o dôležité mestá, ako boli hlavné mestá

8 Podnet pre neoficiálny vznik spoločnej kancelárie v roku 1873 predstavovala Svetová výstava vo Viedni konaná v tomto roku. Hlavná produkcia sa viaže na obdobie rokov 1873 - 1914, po vypuknutí 1 . svetovej vojny prišlo značne rýchlo k ukončeniu činnosti z dôvodu úmrtia architektov a následných finančných problémov. Obdobie hlavnej činnosti sa vzt’ahuje na éru silnej industrializácie a nárastu miest, vzmáhajúcich sa vd’aka meštianstvu. Kancelária zamestnávala cca 20 zamestnancov, ktorí niekedy pracovali na tridsiatich rôznych projektoch zároveň. Počas celej histórie prešlo kanceláriou okolo 360 architektov. KLEIN, Dieter. Das Büro Fellner \& Helmer. In DIENES, Gerhard Michael (ed.). Fellner \& Helmer - Die Architekten der Illusion: Theaterbau und Bühnenbild in Europa; anlässlich des Jubiläums „,100 Jahre Grazer Oper “. Graz: Stadtmuseum Graz, 1999, s. 48. ISBN 3900764212.

9 FELLNER, Ferdinand. Die Entwicklung des Theaterbaues in den letzten fünfzig Jahren. Ein Vortrag, gehalten am 26. November 1909 in der Zentralvereinigung der Architekten der im Reichsrate vertretenen Königreiche und Länder in Wien. Wien: im Selbstverlag des Verfassers, 1909. K téme pozri MORAVČÍKOVÁ, Henrieta. Zrod moderného mesta: zmeny obrazu slovenských miest v druhej polovici 19. a prvej polovici 20. storočia. In Forum historiae: odborný internetový časopis pre históriu a príbuzné spoločenské vedy, 2016, roč. 10, č. 2, s. 1-11. ISSN 1337-6861.

10 Kancelária produkovala rôzne projekty, okrem divadiel pripravila návrhy na niekol'ko nákupných centier (viaceré z nich patrili firme Thonet), palácov, hotelov a rodinných viliek, mauzóleí a fabrík. Sammelwerk der ausgeführten Bauten und Projekte in den Jahren 1870/1914. Wien: Fellner \& Helmer; K. K. Oberbauräte Wien, [ca. 1915], 52 s. 
monarchie (Viedeň, Budapešt') alebo krajov (Graz), d'alej menšie mestá v provincii (Brno, Prešporok), potom mestá s vel'kou tradíciou a kontinuitou v divadelnej histórii (Praha), ako aj mestá s doposial' žiadnou divadelnou históriou, pre ktoré nové divadlo znamenalo nový začiatok (Jablonec nad Nisou). Niektoré miesta ako napr. letné kúpel'né mestečká obývalo bohaté obyvatel'stvo (Karlove Vary, Baden), iné zas mali nízky počet obyvatel'ov a našiel sa tam jeden bohatý mecén umenia (Berndorf).

Architektonické návrhy divadiel z kancelárie Fellner a Helmer nemali nepriaznivý dopad na pôvodnú architektúru miest, ako tomu bolo v prípade niektorých iných divadelných projektov postavených $\mathrm{v}$ historickom centre mesta a vyžadujúcich si vybudovanie vel'kých ulíc na úkor zničenia malých uličiek. Viedenský ateliér najprv preštudoval urbanistickú siet' a následne navrhol postavenie nového divadla na okraji historického centra mesta, resp. na hranici starého a nového mesta. Týmto zachoval pôvodnú mestskú architektúru a zároveň vytvoril nové centrum $\mathrm{v}$ jadre rozšírených oblastí mesta, obývaných novou spoločenskou vrstvou. Výber miesta odzrkadl'oval úlohu mestských divadiel: vychádzali z divadelnej histórie, zároveň prinášali niečo nové a predovšetkým stáli v centre (novej) spoločnosti. Situovanie Mestského divadla v Prešporku do čela Promenády (dnešné Hviezdoslavovo námestie) bolo čiastočne pokračovaním tradície, ked’že predchádzajúca divadelná budova stála takmer na rovnakom mieste. Zároveň sa vytýčilo nové centrum, kde divadlo stálo na čele novopostavených meštianskych domov. Súčasne stavba spĺn̆ala bezpečnostné predpisy, ktoré žiadali postavenie divadla na vol'nom priestranstve $\mathrm{z}$ dôvodu nebezpečenstva požiaru.

Čo sa týka finančných nákladov, kancelária podl’a zachovaných záznamov dodržiavala finančné rozpočty projektov, ba niekedy prekvapila objednávatel’a projektu vrátením preplatku alebo skorším ukončením stavby. O nové projekty sa kancelária uchádzala bud' v sút'aži, alebo nová ponuka nasledovala vzápätí po úspešnom odovzdaní novej stavby. S viedenským projektom prichádzala do miest práca viedenských sochárov a maliarov, čím sa šírilo viedenské remeslo v rámci celej rakúsko-uhorskej monarchie. Pri stavbe používali moderné postupy a ohňovzdorné materiály, ako bol železobetón, železné stípy a podobne. Projektom dominoval architektonický štýl historizmus. Secesný štýl vykazujú stavby po roku 1900 a pochádzajú z dielne synov obidvoch architektov alebo iných zamestnancov kancelárie. Samotní architekti len zriedka hovorili pri svojich projektoch o použitom štýle, občas prišla požiadavka zo strany objednávatel'a. Architektonický štýl nestál v ceste funkcii stavby, divadlá sa projektovali predovšetkým ako divadelné budovy so všetkými náležitost'ami a bezpečnostnými predpismi.

Vyššie spomínané zmeny $\mathrm{v}$ architektonicko-stavebnom riešení divadiel priniesli po roku 1880 členenie budovy na tri časti: vchod (foyer), ktorý bol chá- 
paný ako miesto stretnutia, d’alej hl'adisko ako miesto zhromaždenia sa a napokon javisko ako miesto deja. Toto členenie zodpovedalo sociálnej úlohe divadla: publikum sa v divadle spoznávalo, stretávalo a medzi sebou komunikovalo. Zároveň napíňalo obsah nových bezpečnostných predpisov, ktoré boli vydané v roku 1882 po vel'kom požiari vo viedenskom Ringtheater v roku 1881. Fellner a Helmer zákony implikovali do praxe vel'mi šikovne, dá sa povedat', že sa aktívne podiel'ali na ich rozšírení. Zákony sa netýkali len využitia ohňovzdorných stavebných materiálov, ale predovšetkým nového vonkajšieho a vnútorného členenia divadelnej budovy. Prvým projektom, v ktorom viedenská kancelária uplatnila členenie na tri časti, bolo divadlo v Rijeke, postavené v rokoch 1883 - 1885. V jednotlivých divadelných projektoch možno badat' rozdiely podl'a významu miesta a divadelnej stavby v živote mesta. Prešporské Mestské divadlo nesie jasné stopy trojdielneho členenia budovy a jeho foyer architekti naprojektovali vel'koryso a vel'mi ozdobne. Potvrdzuje to skutočnost' o úlohe divadla ako mieste reprezentácie lokálneho meštianskeho obyvatel'stva. Steny krášlili nástenné mal'by a štukatérska výzdoba z dielne domácich majstrov ako prejav lokálnej identity.

Ďalším dôležitým architektonickým prvkom bola fasáda divadelnej budovy. Podobne ako trojdielne členenie mala okrem technickej funkcie kultúrno-spoločenskú úlohu. Do roku 1905 boli takmer všetky fasády navrhované v historickom štýle a delili sa na štyri typy: chrámový typ so stĺpmi poukazujúci na vznešenú úlohu divadla, d’alej motív loggie vyjadrujúci majestátnost' budovy, potom prvok portálového oblúku inšpirovaný francúzskou renesanciou a napokon motív veže, ktorý dominoval v divadlách zdôrazňujúcich národnú a politickú úlohu divadla. ${ }^{11}$ Túto funkciu pripomínali aj busty na priečelí budovy vyjadrujúce prostredníctvom literárnych vzorov dramatickú tradíciu národa. ${ }^{12} \mathrm{Na}$ priečelí sa nachádzal aj názov divadla odkazujúci na „majitela“a budovy. Čo sa týka Prešporka, pre Mestské divadlo viedenský ateliér navrhol fasádu s motívom vol'no stojacej loggie poukazujúcej na snahu meštanov o vybudovanie honosného stánku vzdelania a vznešenej zábavy. Išlo o dôležitý motív, použitý aj pri

11 MORAVČÍKOVÁ, Henrieta - DLHÁŇOVÁ, Viera. Universal Values and National Symbolism. Theatre and Architectural History in the Slovak Republic. In KOVAČEVIĆ, Igor (ed.). Beyond Everydayness: Theatre Architecture in Central Europe. Praha: Národní divadlo, 2010, s. 65. ISBN 9788072583645. Ďalej pozri MORAVČÍKOVÁ Henrieta - DLHÁŇOVÁ, Viera. Divadelná architektúra na Slovensku. Bratislava: Divadelný ústav, 2011. ISBN 9788089369355.

12 O význame búst umiestňovaných na fasády divadelných budov pozri GROSSEGGER, Elisabeth. Kulturpolitik und Theater in der Reichshauptstadt Wien. Die frühe und die verspätete kulturpolitische Mission des k.k. Hofburg- und Nationaltheaters. In THER, Philipp (ed.). Kulturpolitik und Theater. Die kontinentalen Imperien in Europa im Vergleich. Oldenbourg: Böhlau, 2012, s. 68. ISBN 9783205784913. 
stavbe operných domov vo Viedni a Paríži. V rámci projektov Fellnera a Helmera sa vyskytuje napr. pri divadle v Záhrebe, Zürichu a Liberci (tzv. Scheinloggia).

$\mathrm{K}$ d’alším dominantným prvkom divadla patrilo schodište. Vd’aka dôrazu na bezpečnost' získalo spolu s komunikačnou funkciou novú reprezentačnú úlohu - publikum chcelo vidiet' a súčasne chcelo byt' videné. Fellner a Helmer používali typy schodísk podl'a francúzskeho systému. Prvým bolo centrálne hlavné schodisko, ktoré začínalo uprostred vestibulu a rozdel'ovalo sa na podeste na dve bočné ramená ústiace do foyer a chodieb. Chodby, ktoré nadobudli v tomto období pre divákov dôležitost' ako centrálne miesta pohybu po divadle, boli projektované vel'koryso vrátane všetkých bezpečnostných prvkov. Ďalším typom bolo diagonálne schodište, pri ktorom sa architekti zámerne zriekli centrálneho schodišt’a vyžadujúceho si väčší priestor. Diagonálne schodište bolo riešením pre dosiahnutie úspory priestoru, vd’aka čomu aj divadlá postavené na menšom pozemku mohli mat' dostatočne vel'kú kapacitu. Z plánov Fellnera a Helmera je poznat', že divadlá postavené pred a okolo roku 1882 mali bud' miešané, alebo neurčité formy schodišta, pretože pokial' nebol jasne navrhnutý typ diagonálneho schodiska, architekti riešili tento prvok rozličným spôsobom. To platilo aj pre Prešporok, tunajšie divadlo patrilo $\mathrm{k}$ jedným z prvých divadelných projektov spoločnej kancelárie Fellner a Helmer.

Čo sa týka hl'adiska, bývalo usporiadané stupňovito (typ „,Rangtheater"). Výhoda tohto stavebného riešenia tkvela $\mathrm{v}$ priblížení väčšieho počtu divákov javisku, pričom odstupňovanie zároveň slúžilo na „zobrazenie“ hierarchie sociálneho systému. Aj ked' sa spoločnost' demokratizovala a meštianstvo tvorilo stále publikum, predsa pretrvali rozdiely, ktoré sa $\mathrm{v}$ rámci divadla odzrkadlili vo výbere miest na sedenie. V hl’adisku boli navrhnuté lóže, lóže spolu s balkónmi alebo len balkóny a k tomu vyhradený priestor na státie. Väčšina hl’adísk obsahovala kombinácie priechodných lóží a balkónov, čím sa zvýšila kapacita bez rozširovania samotného priestoru hl'adiska. Hl'adisko v Mestskom divadle v Prešporku bolo naprojektované do troch poschodí a hornej galérie. Miesta na sedenie boli na prízemí, $v$ lóžach na prízemí, prvom a druhom poschodí a na balkóne na druhom a tret'om poschodí. Miesta na státie boli na prízemí, na tret’om poschodí a na galérii.

Pri pohl'ade na rozdielnost' divadelných projektov a zároveň ich spoločné črty možno povedat', že divadlá na seba navzájom pôsobili. Väčšina projektov viedenskej kancelárie niesla pomenovanie mestské divadlá a slúžila mestskému obyvatel'stvu, z čoho plynie ich poslanie a čiastočná eklektickost', blízka podobným esteticko-spoločenským predstavám o svete. Prácu viedenských architektov Fellnera a Helmera možno považovat' za kultúrne dedičstvo rakúsko-uhorskej monarchie, odkaz minulosti s presahom do budúcnosti. Podobne ako v Prešpor- 
ku sa väčšina mestských divadiel neskôr pretransformovala do národných divadiel, slúžiacich ako nositelia konštitutívnych myšlienok novodobých štátov.

\section{Kultúrno-spoločenské prostredie Prešporka na sklonku 19. storočia, kon- texty}

Pri pohl'ade na dlhoročnú históriu mesta Prešporka sa javí pozvanie viedenských architektov do Prešporka viac než logické. Viedenská kancelária sa ako autor novej divadelnej budovy stala mostom medzi včerajškom a zajtrajškom a zároveň dala mestu punc dôležitosti. Blízkost' Viedne mala na spoločenský a kultúrny život obyvatel'ov Prešporka vel'ký dosah. Obyvatel'stvo vedome napodobňovalo spôsob života Viedenčanov a cítilo sa byt' významným článkom v spoločnej minulosti. Úzka spätost' s cisárskym mestom, ktorá tkvela v skutočnosti, že Prešporok sa od roku 1536 stal sídelným a korunovačným mestom Uhorska, hlboko poznačila jeho kultúrne dejiny. Mária Terézia a jej časté návštevy prispeli $\mathrm{k}$ hospodárskemu a umeleckému rozvoju mesta a pestovanie hudby i divadla na vysokej úrovni bolo dôvodom častej prítomnosti významných umelcov v meste.

Z hl'adiska zloženia obyvatel'stva sa Prešporok do konca 18. storočia považoval za centrum nemeckého jazykového kultúrneho života krajiny a medzi Prešporčanov patrili osoby pochádzajúce z nemeckých a rakúskych krajín i z územia dnešného Mad'arska. Po skončení tureckého ohrozenia sa rozhodnutím cisára Jozefa II. v roku 1783 uhorské centrálne úrady presunuli do Budína, čo znamenalo hromadný odchod vyššej šlachty z mesta. Prostredníctvom osobných kontaktov s Viedňou sa obyvatelia Prešporka snažili vyvracat' provinčný „imidž“, ktorý mesto rýchlo nadobudlo. Pokojné mesto na Dunaji s obchodnícko-vinohradníckou tradíciou ašpirujúce na pomenovanie „druhé mesto Uhorska“, aj takto možno vyjadrit' obraz Prešporka v druhej polovici 19. storočia.

Nositel'mi kultúry a vzdelania boli väčšinou obyvatelia hovoriaci po nemecky. Aká bola ich príslušnost' k Uhorsku, vypovedá ich správanie poukazujúce na patriotizmus, hrdost' na krajinu, do ktorej patrili. ${ }^{13}$ Pomenovanie Deutschungarn (nemeckí Uhri) hodnotilo ich vzt'ah k Uhorsku, ktorého tradície považovali za vlastné. Dôležitejší bol však osobný vzt’ah k Prešporku, ktorý možno označit' za lokálpatriotizmus prejavujúci sa živým záujmom o spoločenský a kultúrny rozvoj mesta. Hrdost' na bohatú minulost' bola silnejšia ako neistá súčasnost' a návraty do histórie skrze miesta pamäti pripomínali reminiscencie „starej Viedne“. Voči uhorskej vláde sa chovali lojálne a neustále poukazovali na oddanost' pri slávení uhorských národných sviatkov.

13 MANNOVÁ, Elena. Sebaprezentácia nemeckých stredných vrstiev v Bratislave v 19. storočí. In Slovenský národopis, 1995, roč. 43, č. 2, s. 170. ISSN 1335-1303. 
Snaha o verejné prejavy lojálnosti voči uhorskej vláde bola dobrým spôsobom, ako získat' určité výhody. Odvolávanie sa na patriotizmus a hlbokú oddanost' Uhorsku však postupne viedla ku kompromisom a vyhýbaniu sa konfliktom s obyvatel'mi hovoriacimi po mad'arsky. Ich rastúci vplyv v lokálnej politike považovali za prirodzený a nestavali sa mu výrazne na odpor, pokial' neboli ohrozené ich vlastné záujmy. V úsilí o zachovanie spoločenského a verejného postavenia, ktoré bolo pre nich dôležité, boli ochotní pristúpit' k pomad'arčeniu mien. Išlo o uprednostnenie sociálnych výhod aj za cenu zrieknutia sa pôvodnej etnickej identity. ${ }^{14}$

V zhode so spoločenskými zmenami doby platilo, že rámci verejného života rozhodoval sociálny status. Ten sa okrem lokálneho politického života demonštroval viacnásobnou účast'ou v rozličných prešporských mestských spolkoch. Väčšina z nich mala nemecko-mad'arský charakter, ba dokonca aj v prípade tých, ktoré mali za ciel' podporu a šírenie mad'arského jazyka. Čo sa týka umeleckých spolkov, počas 19. storočia ich v Prešporku vzniklo niekol'ko. Najznámejším hudobným spolkom bol nepochybne Cirkevný hudobný spolok pri Dóme sv. Martina (CHS, nem. Kirchenmusikverein bei der Dom-, Kollegiatsund Stadtpfarrkirche zu St. Martin), ktorý vd’aka svojmu bohatému cirkevnému a svetskému repertoáru predstavoval hlavného nositel’a hudobného života v 19. storočí v Prešporku. Medzi jeho kapelníkov, ktorí CHS viedli počas 19. storočia, patrili uznávané umelecké osobnosti ako Jozef Kumlik, Karl Mayrberger, Joseph Thiard-Laforest, Ludwig Burger. Okrem domáceho prostredia účinkoval CHS aj v zahraničí a vo svojom repertoári mal cirkevnú i svetskú tvorbu Josepha Haydna, Wolfganga Amadea Mozarta, Ludwiga van Beethovena, Franza Schuberta, Franza Liszta, Richarda Wagnera, Johannesa Brahmsa a d'alších. Vel'kou ct'ou pre samotný spolok, ako aj Prešporok bola skutočnost', že koncertov sa zúčastnili samotní autori diel (k najznámejším možno zaradit' Franza Liszta, ktorý opakovane koncertoval v Prešporku) a známi interpreti (Joseph Joachim, Géza Zichy, Eugen d'Albert, Anton Rubinstein). Čestným členom spolku bol aj dirigent Hans Richter.

Vznik speváckych spolkov v 19. storočí, ktorým v rámci hudobného a divadelného života Prešporka patrilo dôležité miesto, podmieňoval jednak záujem meštianstva o zdôraznenie výchovno-vzdelávacieho aspektu umenia a jednak zál'uba v zborovom speve. Spoločné vystupovanie bolo dobrou príležitost’ou

14 TANCER, Jozef - MANNOVÁ, Elena. Od uhorského patriotizmu k menšinovému nacionalizmu. Zmeny povedomia Nemcov na Slovensku v 18. až 20. storočí. In KILIÁNOVÁ, Gabriela - KOWALSKÁ, Eva - KREKOVIČOVÁ, Eva (eds.). My a tí druhí v modernej spoločnosti. Konštrukcie a transformácie kolektívnych identít. Bratislava: Veda - vydavatel'stvo Slovenskej akadémie vied, 2009, s. 376, 389. ISBN 9788022410250. 
k skupinovej reprezentácii a pozitívne vplývalo na kolektívnu identitu. ${ }^{15} \mathrm{~K}$ najznámejším patril mužský spolok Liedertafel, d’alej miešaný spolok Singverein, ktorý účinkoval v rámci koncertov CHS (zbormajstrom spolku Singverein bol Anton Strehlen, dlhoročný člen CHS a neskorší jeho vedúci) a občasne vypomáhal v Mestskom divadle a napokon pôvodne mužský robotnícky spolok Typographenbund, ktorý sa rýchlo transformoval do miešaného zboru a taktiež úspešne účinkoval v operných predstaveniach v Mestskom divadle.

K umeleckým strediskám patrili aj nad’alej šlachtické rezidencie. Významným podporovatel'om umenia bola rodina arcivojvodu Fridricha a jeho manželky Izabely, ktorí obývali v Prešporku Grassalkovichov palác. Arcivojvoda Fridrich stál na čele vojenského velitel'stva rakúsko-uhorskej armády, ktoré sídlilo v Prešporku. Na vojenskom velitel'stve pôsobil rad vzdelaných mužov z aristokratických kruhov, ktorí sa podiel'ali na spoločenskom živote mesta. Z najznámejších šlachtických rodín, obývajúcich v druhej polovici 19. storočia Prešporok, možno spomenút' mená Esterházy, Pálffy, Batthyány. Okrem šlachtických domov sa hudobné umenie v 19. storočí pestovalo vo významných meštianskych rodinách, ako boli David, Dohnányi, Kováts, Loschdorfer, Mauthner, Ovary, Rigele, Tranta, Simonyi, Spányik. ${ }^{16}$ Hudobné vzdelanie a domáce muzicírovanie patrili k dobrej výchove, komorná hudba znela na súkromných, poloverejných a verejných koncertoch. V rámci nástrojov mešt’ania uprednostňovali klavír, ktorý dopíňala výučba spevu. V meste pôsobili viacerí súkromní učitelia klavíru, ked’že do roku 1906 v Prešporku neexistovala hudobná škola. Hudobný život v meste výrazne obohacovali aj vojenské kapely, menovite kapela 72. pešieho pluku na čele s kapelníkom Franzom Scharochom. Ďalšou vojenskou kapelou bola honvédska kapela pod vedením Josefa Stritzla. Obraz hudobného Prešporka na sklonku 19. storočia dopíňali rómske kapely s oblúbenými vystúpeniami v lokálnych kaviarňach.

Budapešt' aj Viedeň vnímali Prešporok v 19. storočí ako provinčné mesto na západe Horného Uhorska, pričom s postupujúcou mad'arizáciou ho označovali niektorí uhorskí politici za západnú baštu mad’arstva. Zo strany prešporských promad'arských kruhov zaznievali názory o novom divadle ako prostriedku posilnenia myšlienky o jednom (mad'arskom) národe. ${ }^{17}$ Stavba verejných budov bola zároveň dobrým prostriedkom, ako demonštrovat' kultúrnost' mesta a jej

15 NIPPERDEY, Thomas. Wie das Bürgerthum die Moderne fand. Berlin: Siedler, 1988, s. 13.

16 LENGOVÁ, Jana. Pressburg im letzten Drittel des 19. Jahrhunderts - das Musikmilieu der Jugendjahre Franz Schmidts. In OTTNER, Carmen (ed.). Franz Schmidt und Pressburg. Wien: Doblinger, 1999, s. 11, 16. ISBN 390069544.

17 K téme národ ako sociálna reprezentácia pozri VÖRÖS, László. Analytická historiografia versus národné dejiny. „Národ“ ako sociálna reprezentácia. Pisa: Plus-Pisa University Press, 2010. ISBN 9788884927415. 
obyvatel'ov. Označenie ,provinčné“ považovali Prešporčania vzhl'adom na slávnu minulost' svojho mesta za urážajúce a snažili sa mu všemožne vyhnút'. Návšteva divadelných predstavení patrila k neodmyslitel’nej súčasti ich spoločenského života a tvorila rámec kolektívnej reprezentácie. Rozhodnutie postavit’ novú budovu pre potreby divadla možno preto vnímat' ako dôsledok snahy o posilnenie kolektívnej meštianskej identity a ako túžbu vyrovnat' sa mestám s podobnou skladbou a vel'kost'ou obyvatel'stva.

\section{Projekt nového Mestského divadla}

V druhej polovici 19. storočia rástol počet obyvatel'stva Prešporka, čo sa odrazilo aj v návštevnosti divadla. Kapacita divadelnej budovy z roku 1776 sa postupne stávala nedostačujúcou a jej stav už nezodpovedal bezpečnostným predpisom. Na jeseň roku 1879 pri koncerte CHS v sále Reduty padol z plafóna kúsok muriva, čo okamžite vzbudilo zvýšený záujem o bezpečnost' divadla, pretože sála bola jeho súčast'ou. Mesto rozhodlo o zostavení dvanást'člennej komisie ${ }^{18}$ a poverilo ju vypracovaním posudku o stave divadelnej budovy. Po podrobnom prehliadnutí divadla komisia konštatovala nebezpečenstvo požiaru z viacerých dôvodov. Budova jednak nedisponovala samostatnými priestormi na uskladnenie kulís a dekorácií, preto boli uložené za javiskom a na povale Reduty. Kulisy a dekorácie boli vyrobené prevažne $\mathrm{z}$ horl'avých materiálov, ktoré v prípade požiaru mohli zapríčinit' rozsiahle škody. Budova mala d’alej málo únikových východov a východ z nej bol obtiažny, ked’že chodby boli úzke. Komisia d’alej poukázala na nedostatočnú ventiláciu, ako aj absenciu železnej opony, ktorá by zamedzila šŕreniu sa prípadného požiaru $\mathrm{z}$ javiska. ${ }^{19}$ Pre potvrdenie zistených výsledkov o zlom technickom stave budovy mesto prizvalo uznávaných viedenských architektov Ferdinanda Fellnera ml. a Otta Hofera. Obidvaja začiatkom roku 1880 vykonali prehliadku starého divadla, stotožnili sa s názorom komisie a zároveň vyjadrili záujem podiel'at' sa na novom divadelnom projekte. ${ }^{20}$

V mestskom zastupitel'stve sa otvorila diskusia, či je potrebné divadlo zbúrat' a postavit' nové, alebo staré nechat' zrekonštruovat'. Koncom roku 1881 dospel

18 Členmi komisie boli mestský kapitán Johann Kozsehuba, hlavný mestský inžinier Anton Sendlein, úradný lekár Dr. Georg Kováts, velitel' hasičského zboru Ferdinand Martinengo, stavební majstri Ignátz Feigler, Ludwig Eremit, Martin Köszler a tesársky majster Moritz Sprinzl, d’alej reprezentanti municipálneho výboru Carl Koller, princ Arthur Rohan, Josef v. Jeszenszky a Josef v. Záborszky. Prehliadka starého divadla sa konala 17. 12. 1879. AMB, Magistrát, Mestské zariadenia - Divadlo, spisy.

19 Komisia taktiež upozornila na absenciu vhodných hygienických zariadení pre návštevníkov, ako aj pre účinkujúcich. Archív mesta Bratislavy, Magistrát mesta Bratislavy, Mestské zariadenia XI/5 - Divadlo, spisy z rokov 1886 - 1898, kartón 2940 (d’alej AMB, Magistrát, Mestské zariadenia - Divadlo, spisy).

20 AMB, Magistrát, Mestské zariadenia - Divadlo, spisy. 
municipálny výbor ku konečnému rozhodnutiu, že nechá postavit’ nové divadlo a zároveň poverilo stavbou viedenskú kanceláriu Fellner - Helmer. ${ }^{21}$ Tá dodala $\mathrm{v}$ decembri 1881 hotové plány, avšak takmer súčasne s odovzdaním plánov prišlo ku katastrofe vo viedenskom Ringtheater a k starej budove museli byt' urýchlene postavené núdzové schody, inak hrozilo zatvorenie divadla. Vedelo sa, že ide o provizórne riešenie, kým Budapešt' neodsúhlasí plány na novostavbu. Ked’že sa ale po požiari sprísnili bezpečnostné opatrenia, odpoved' znela, že hotové plány treba prepracovat..22

Medzitým sa začala nová sezóna 1882/1883 a v municipálnom výbore vznikol nápad, že by starú budovu stačilo len prestavat'. Riešenie vyzeralo opät' provizórne, stačilo však na odsúhlasenie otvorenia d’alšej sezóny 1883/1884. Koniec dlhotrvajúcich debát nastal, ked' hlavný mestský inžinier Anton Sendlein odmietol vydat' povolenie na otvorenie sezóny. Mestský kapitán Kozsehuba urýchlene odcestoval do Budapešti, kde ministerstvo vnútra potvrdilo Sendleinov zákaz o používaní divadelnej budovy. Budova bola označená za technicky nedostačujúcu a mestu odporučili postavenie novej budovy. ${ }^{23}$

Prešporok tak začal od roku 1879 uvažovat' o postavení nového divadla, ku konečnému rozhodnutiu prišlo po dlhej diskusii na základe požiadavky uhorskej vlády v roku 1884 . Rokovania o rozhodnutí, ako aj obsah diskusí́ k postaveniu nového divadla sú príkladom zmien, ktoré sa diali v Prešporku na sklonku 19. storočia. Stavba nového Mestského divadla v Prešporku nebola v tom čase v rámci rakúsko-uhorskej monarchie výnimkou, práve naopak. Mešt’ania chceli mat' budovu, ktorá by ich reprezentovala, zároveň ale vedeli, že divadlo nestačí len postavit', ale predovšetkým ho treba udržiavat'. Odhodlanie k činu nakoniec dozrelo pod vplyvom politického rozhodnutia.

Posledné predstavenie v starej divadelnej budove v rámci riadnej sezóny odohrali 6. apríla 1884. Ako host' v hre Der Hypochonder (G. v. Moser) vystúpil rakúsky herec Dr. Rudolf Tyrolt, ktorý celý týždeň host’oval v Prešporku. Uvedené dielo bolo dost' obohrané, kritik preto reagoval s odstupom, pretože bol sklamaný, že na poslednú chvíl'u prišlo k zmene programu. Okrem toho ,nebolo

21 V AMB sa nachádzajú listy od Ferdinanda Fellnera ml., ktorý mal v rámci spoločnej viedenskej kancelárie na starosti projekt v Prešporku. AMB, Magistrát, Mestské zariadenia - Divadlo, spisy.

22 Ferdinand Fellner ml. a Hermann Helmer boli členmi komisie, ktorú po požiari v Ringtheater zostavil Spolok rakúskych inžinierov a architektov za účelom vypracovania odporučení pre zvýšenie bezpečnosti divadelných stavieb. Vedeli preto, že pôvodný projekt bude nutné v značnej miere prepracovat'. Vo fonde AMB sa nachádza kópia spomínaných odporučení s menami členov komisie. AMB, Magistrát, Mestské zariadenia - Divadlo, spisy.

23 FABRICIUS, Otto von. Das neue Theater in Preßburg. Festschrift. Preßburg: Druckerei des Westungarischer Grenzbote, 1886, s. 6-9. 
dôstojným ukončením " divadelných predstavení v starej budove. ${ }^{24} \mathrm{Od} 13$. apríla do 29. mája host'ovala v divadle mad'arská divadelná spoločnost', v ktorej ako hlavný režisér pôsobil neskorší mad'arský divadelný riaditel' nového Mestského divadla Ignácz Krecsányi.

Denník Preßburger Zeitung v nasledujúcich týždňoch informoval, že 26. júna bolo z ministerstva vnútra mestu doručené povolenie na demoláciu starého a stavbu nového divadla. Na zasadaní municipálneho výboru 19. augusta sa reprezentanti uzniesli na potrebných prípravných prácach, $\mathrm{v}$ rámci ktorých vyzvali majitel’ov rodinných lóží v starom divadle, resp. právnych nástupcov pôvodných majitel'ov, aby si z divadla odniesli svoje súkromné veci. ${ }^{25}$ Koncom septembra prišlo k dlhoočakávanej demolácii. Dňa 25. septembra bola stavba vydaná do rúk stavitel'ov Ignatza Feiglera, Alexandra Feiglera a Moritza Sprintzla, ktorí boli poverení stavbou nového divadla. Starú budovu demolovali postupne, divadelná kancelária a denná kasa zostali podl’a záznamov počas prvých týždňov zachované. ${ }^{26}$ Nasledovalo dvojročné obdobie očakávania príchodu novej Tálie, pričom divadelné predstavenia $\mathrm{v}$ meste pokračovali i nad'alej. Mesto požiadalo o zriadenie dočasnej divadelnej scény v Pálffyho záhrade. Priestory upravil hlavný inžinier Sendlein, a aj ked' sa jednalo o provizórne priestory, otváracie predstavenie bolo zaranžované ako skutočná slávnost' ${ }^{27}$ Vd’aka tejto dočasnej scéne sa neprerušila kontinuita $\mathrm{v}$ divadelnej tradícii mesta.

\section{Nová budova a jej slávnostné otvorenie}

Blížil sa 22. september 1886 a s ním dlho očakávané slávnostné otvorenie novej divadelnej budovy. Otto von Fabricius v brožúrke vydanej k otvoreniu nového divadla, ako aj v správach uverejnených $\mathrm{v}$ denníkoch, pri opise interiéru a exteriéru budovy kládol dôraz na dva prvky, ktoré boli (podobne ako počas otvorenia starého divadla) klúčové pre divadelné publikum: bezpečnost' divadla a krása budovy skombinovaná s pohodlím. Ked’že práve tieto prvky sa spomínali v súvislosti s obhliadkami starej budovy a mali byt' dôvodom pre zbúranie starého divadla, Fabricius na ne opakovane poukazoval.

24 -a-: Gastspiel Tyrolt. In Preßburger Zeitung, 7. 4. 1884, roč. 121, č. 97, s. 3.

25 Medzi pôvodnými majitel'mi lóží sú vymenovaní gróf Anton Grassalkovich, gróf Johann Illésházy, gróf Emerich Csáky, barón Balassa, gróf Christof Erdödy, grófka Clara Castiglioni, gróf Leopold Pálffy, gróf Franz Zichy, gróf Georg Apponyi, gróf Ludwig Csáky, gróf Karl Andrássy, gróf Franz Esterházy, gróf Nicolaus Forgách. Aufruf. In Preßburger Zeitung, 24. 8. 1884, roč. 121 , č. 234, s. 2.

26 Preßburger Zeitung, 25. 9. 1884, roč. 121, č. 265, s. 3.

27 Predstavenia začali 1. októbra 1884 a obidve sezóny (1884/1885 a 1885/1886) mal na starosti divadelný riaditel' Karl Ludwig Zwerenz (1850 - 1925), otec operetnej speváčky Mizzi Zwerenz (1876 - 1947). -a-: Eröffnungs-Vorstellung. In Preßburger Zeitung, 2. 10. 1884, roč. 121, č. 272 , s. 4. 
Podl'a opisov naprojektovali Ferdinand Fellner ml. a Hermann Helmer nové divadlo podl'a najmodernejších bezpečnostných požiadaviek v historickom neorenesančnom štýle s vnútornou neobarokovou výzdobou. Jednou z technických noviniek po zavedení nových bezpečnostných predpisov bolo oddelenie javiska od ostatných častí budovy ohňovzdornými stenami, ktoré boli ukončené vo vysokom povrazisku. Ďalším bezpečnostným prvkom bolo zabudovanie železnej opony, takže javisko a hl'adisko už nestálo pod jednou strechou. Autorom železnej opony bol prešporský umelecký zámočník L'udovít (Lajos, Ludwig) Márton. ${ }^{28} \mathrm{~K}$ dôležitému riešeniu bezpečnosti $\mathrm{v}$ budove patrilo množstvo východov z hl'adiska, ktoré ústili do spevnených klenutých chodieb chrániacich pred možným požiarom.

Bezpečnost' malo zabezpečit' aj nové plynové osvetlenie. Z plafóna v hladisku visel vel'ký pozlátený luster, ktorého zapal'ovanie prebiehalo prostredníctvom elektrického spojenia priamo z javiska. Orchester osvetl'ovali z bezpečnostných dôvodov olejové lampy, sviečky sa v divadle používali len zriedka. ${ }^{29}$

Divadlo malo kapacitu približne 1200 osôb. ${ }^{30}$ Počet miest bol primeraný $\mathrm{k}$ vel'kosti budovy. Komfort a pohodlie pre účinkujúcich poskytovalo dobré vybavenie šatní, priestor na odkladanie rekvizít, väčšie a modernejšie javisko. Publikum zasa ocenilo pohodlnejšie miesta na sedenie, ktoré boli usporiadané tak, aby aj z najvyššieho poschodia bol dobrý výhl'ad na javisko. Divadlo disponovalo priestrannými šatňami, bufetom a balkónom, široké chodby boli vhodným miestom na prechádzanie sa počas prestávok.

Ďalšou stránkou, ktorú pri opise novostavby denníky zdôrazňovali, bola spolupráca lokálnych majstrov na novostavbe, ktorých počet bol vyšší než počet majstrov z Viedne a Budapešti. Umiestnenie hodnotných diel domácich umelcov

28 Opona visela na ôsmich železných lanách, bola dvanást' metrov široká a devät' a pol metra vysoká a vd’aka najnovšiemu technickému systému bola schopná „spadnút““ do desiatich sekúnd. Roku 1911 bola železná opona skrášlená návrhom od Gustava Wintersteinera s motívom veduty Prešporka v pozadí.

29 V rokoch 1904 - 1906 sa v účtovných knihách mesta Prešporka uvádza položka za zriadenie elektrického osvetlenia a ventilácie, čo potvrdzuje vyššie uvedenú informáciu, že osvetlenie v divadle bolo na začiatku plynové. Pozsony szabad. királyi város zárszámadása és vagyonleltára/Schluss-rechnung und Vermögens-inventar der königlichen Freistadt Preßburg. Pozsony: Nyomatott Angermayer Károly nyomdaintézetében, 1904, 1905, 1906, s. 25.

30 K celkovej kapacite divadla sa nachádza viacero údajov. V plánoch k novému divadlu sa Ferdinand Fellner ml. zmieňuje o počte 1236 miest. AMB, Magistrát mesta Bratislavy, Mestské zariadenia XI/5 - Divadlo, spisy z rokov 1881 - 1885, kartón 2939. Otto von Fabricius uvádza počet 1167 osôb. FABRICIUS, ref. 23, s. 14. Denník Preßburger Zeitung píše pred otvorením divadla o kapacite 1200 osôb. Das neue Pressburger Stadttheater. In Preßburger Zeitung, 18. 3. 1886, roč. 123 , č. 77 , s. 2-3. Kapacitu 1170 osôb spomína nemecký almanach. Almanach der Genossenschaft Deutscher Bühnen-Angehöriger (Gettke's Bühnen-Almanach). Leipzig: Verlag von Karl Reissner, 1887, s. 268. 
$\mathrm{v}$ interiéri divadla malo svedčit' o kvalite domáceho umenia. Steny vo vestibule boli zdobené mal'bami od Kornela Spányiho (1858 - 1943), ktoré zobrazovali alegóriu štyroch múz: drámy, frašky, hudby, tanca. ${ }^{31}$ Ďalším umelcom, ktorého otec bol prešporským rodákom, bol Willibald Leo Freiherr von Lütgendorff Leinburg (1856 - 1937), autor nástenných malieb na strope hl'adiska. Mal'by reprodukovali výjavy z uhorských historických hier - Bánk bán, Hunyadi László, Csongor és Tünde a postavu staromad'arského pohanského kňaza Táltosa, rozprávajúceho okolostojacim mladíkom slávne uhorské ságy. Ďalej sa spomínalo plánované postavenie fontány pred divadlom, ktorej autorom sa stal prešporský rodák žijúci vo Viedni Viktor Tilgner. Fontánu darovala mestu Prvá prešporská sporitel'ňa. Okolie malo byt' dôstojne upravené vydláždenými chodníkmi, čo zavŕšilo dojem kompletne dokončenej novostavby. ${ }^{32}$

Súčast'ou opisov bola aj chvála uhorského patriotizmu, ktorý Prešporčania zviditel'nili v kl'účových stavebných a dekoratívnych prvkoch. Prvým z nich boli nesporne busty umiestnené do oválnych otvorov nad loggiou na fasáde budovy. Popri svetových dramatikoch (Johann Wolfgang Goethe, William Shakespeare) vybrali Prešporčania dvoch významných mad’arských dramatikov (Mihály Vörösmartyho, Josefa Katonu), ktorí spolu s bustou Franza Liszta naznačili, „kto bude v divadle doma“. Ich autorom bol budapeštiansky sochár W. Marhenke. ${ }^{33}$ Ďalším prvkom bol mad’arský nápis Városi színház, t. j. Mestské divadlo na priečelí budovy. V mad’arčine boli zostavené aj texty na pamätných tabuliach vo vestibule divadla. Na jednej z nich stáli mená tých, ktorí sa zaslúžili o výstavbu

31 Kornel Spányi (Kornel von Spányik, 1858 - 1943), pôvodom prešporský maliar pôsobiaci v Budapešti, vo Viedni a v Prahe, brat mezzosopranistky svetového mena Irmy von Spanyik. LASLAVÍKOVÁ, Jana - VYSKUPOVÁ, Martina. Mestské divadlo v Prešporku: [katalóg výstavy: 23. 6. - 11. 9. 2016, Galéria mesta Bratislavy, Pálffyho palác]. Bratislava: GMB, 2016, s. 35. ISBN 9788089340774.

32 Jediným nedostatkom novej budovy bol fakt, že kvôli nariadeniu týkajúceho sa jedného účelu divadelnej budovy nebolo možné postavit' v rámci novostavby sálu Reduty. Prešporčania sa v nasledujúcich rokoch st’ažovali, že mesto nemá priestor na vel'ké koncerty a plesy, ako tomu bolo v starom divadle. Ferdinand Fellner ml. sa k tejto veci vyjadril v tom zmysle, že novopostavené divadlo bude natol'ko uspôsobené, že sa bude môct' využívat' aj na účely usporiadania bálov. Táto možnost' sa nakoniec neujala, v divadle sa hralo denne a plesy sa konali v iných priestoroch. AMB, Magistrát mesta Bratislavy, Mestské zariadenia XI/5 - Divadlo, spisy z rokov $1881-1885$, k. 2939.

33 Medzi portrétovanými osobnost’ami sa napriek silnej väzbe Prešporčanov k Viedni neobjavil žiaden rakúsky básnik alebo skladatel'. Politický podtón výberu potvrdzuje aj skutočnost', že okolo roku $1935 \mathrm{v}$ rámci rekonštrukčných prác v budove boli busty z priečelia odstránené. Mesto plánovalo nahradit' pôvodné busty inými známymi českými a slovenskými osobnost’ami, avšak nakoniec k tomu nedošlo. Busty sa vrátili na pôvodné miesto až v novom tisícročí. Zničená busta Vörösmártyho bola nahradená bustou W. A. Mozarta. BLAHOVÁ, Elena. Busty na priečelí historickej budovy Slovenského národného divadla. In Bratislava: zborník Múzea mesta Bratislavy, zv. 17, 2005, s. 95-104. 
nového divadla (mešt’anosta Prešporka Karl Mergl, architekti Fellner a Helmer, hlavný inžinier Anton Sendlein), druhá zvečňovala mená cisára Františka Jozefa I. a ministerského predsedu uhorskej vlády Kolomana Tiszu, za vlády ktorých bolo divadlo postavené.

Explicitne jasným signálom uhorského patriotizmu bolo slávnostné večerné otváracie predstavenie, ktoré Prešporčania premenili na oslavu svojej obetavosti voči Uhorsku. Programu v divadle predchádzalo doobedňajšie vítanie hostí na vlakovej stanici vyzdobenej uhorskými vlajkami. Mešt’anosta spolu so zástupcami mestskej rady predniesli uvítaciu reč na počest' Kolomana Tiszu a členov jeho sprievodu, do ktorého patrili minister pre náboženstvo a vzdelávanie Agoston Tréfort (1817 - 1888), správca koruny a bývalý ministerský predseda József Szlávy de Érkenéz et Okány (1818 - 1900), významný politik Károly Hieronymi (1836 - 1911) a niektorí poslanci uhorského snemu. Nasledoval slávnostný obed v úzkom kruhu pozvaných, kde zazneli myšlienky o nových časoch: nová budova sa mala stat' domovom nemeckej i mad'arskej múzy. ${ }^{34}$ Zásluhu na tom mali Prešporčania, ktorí vd’aka jednote a svornosti dokázali vybudovat' reprezentatívnu budovu divadelnému umeniu. Na tento aspekt poukázal aj mešt’anosta Karl Mergl, ktorý v kladení posledného kameňa videl symbol pochovania všetkých svárov a nezhôd medzi obyvatel'mi Prešporka. ${ }^{35}$ Slávnost' otvorenia nového divadla sa tak stala symbolom (staro)nových slávnych čias. ${ }^{36}$

V auditóriu slávnostne vyzdobeného divadla sa zhromaždila celá prešporská elita na čele s arcivojvodom Fridrichom a arcivojvodkyňou Izabelou. Z domácej šl'achty bol prítomný gróf Štefan Esterházy, gróf Ernst Esterházy, grófovia Schaffgotsche, d’alej gróf Štefan a Béla Pálffy, gróf Batthyány, barón Duka. $\mathrm{Z}$ vojenských velitel'ov sa $\mathrm{v}$ divadle nachádzal barón Adolf von Catty, generál Zipperer, generál intendant Klaus, šéf generálneho štábu plukovník Franz Xaver von Schönaich, plukovník Josef von Bruna a velitel' žandárstva podplukovník gróf Beckers. ${ }^{37}$

Program otváracieho predstavenia pozostával z nasledovných mad’arských diel: na úvod zaznela hymna, potom Rákoczyho pochod ${ }^{38}$ a napokon budapeštian-

34 Eröffnung des Preßburger Theaters. In Pester Lloyd, 23. 9. 1886, roč. 33, č. 264, s. 3.

35 Der Eröffnungstag des neuen Theaters. In Preßburger Zeitung, 22. 9. 1886, roč. 123, č. 263, s. 2.

36 Scenár otváracej slávnosti, ktorý zostavil Ján Batka, pripomínal scenár korunovačných slávností, ktoré mali pre Prešporčanov z hl'adiska konštruovania lokálnej identity mimoriadny význam. Preßburgs neues Heim der Musen. In Preßburger Zeitung, 22. 9. 1886, roč. 123, č. 263 , s. 2.

37 Der Eröffnungstag des neuen Theaters. In Westungarischer Grenzbote, 23. 9. 1886, roč. 15, č. 4718 , s. 3 .

38 Podl'a informácií na divadelnej ceduli, ako aj správ v denníkoch mal zazniet' slávnostný pochod od Sándora Berthu skomponovaný pre túto príležitost'. V poslednej chvíli prišlo z nezná- 
sky herec Emerich Nagy zarecitoval prológ Lidérczfények (Bludičky) od Mórica Jókaia, ktorý vznikol pri príležitosti otvorenia nového divadla a zaznel v prítomnosti autora. ${ }^{39}$ Vrcholom večera bola opera Bánk bán od Ferenca Erkela ${ }^{40}$ ktorú počas prvého dejstva dirigoval sám skladatel', ostatné dejstvá dirigoval jeho syn Sándor. Uvedený program odznel v podaní členov Mad'arskej král’ovskej opery (Magyar Királyi Opera) a Národného divadla (Nemzeti Színház) z Budapešti, ktorí v Prešporku účinkovali bez nároku na honorár (išlo o kompletné umelecké súbory vrátane sólistov, zboristov a členov orchestra). ${ }^{41}$ Vd’aka ústretovosti intendanta obidvoch umeleckých inštitúcií Istvána Keglevicha sa po otváracom

mych príčin k zmene programu a hral sa Rákoczyho pochod. Berthov pochod nakoniec zaznel pri otvorení nemeckej sezóny 30. 9. 1886. -a-: Harold. In Preßburger Zeitung, 1. 10. 1886, roč. 123 , č. 272 , s. 4 .

39 Prológ bol vel’mi rozsiahly, stavbou aj obsahom pripomínal starodávne ódy, zároveň mal komicko-ironický charakter. V úvode ospevoval vznik mad’arského národa, následne sa venoval vzniku divadelného umenia. V závere pranieroval divadelných kritikov opomínajúcich zložitú situáciu riaditel’ov provinčných divadiel, ktorá bola dramatikovi Jókaiovi známa. Pre svoju otvorenost' si autor vyslúžil tvrdú kritiku vo viedenských novinách. Písali o nej Národnie noviny, ktoré priniesli krátku správu o otvorení nového divadla, ale o to dlhšiu kritiku mad’arského básnika: „Prolog, akého čo do dížky niet snád' vo svete, obsahuje medzi inými ,duchaplnost'ami' aj kritiku kritiky. Táto, chuderka, vel'mi zle pochodila, lebo Jókai vytýka jej, že je nesvedomitá. Verše, v ktorej pán Jókai mydli kritiku, viedeňská ,D. Ztg. 'nazýva ,nevel’mi vkusnými, končia sa takto:

,Tým spôsobom len Thalii útlunkej

Ty hlavu režeš miesto otlaku

Tak nies' lekárom, ale si jej katom!

Aj ty si hlavu posyp popol'om!‘

a ten istý viedeňský časopis sprevádza jich nasledujúcou poznámkou: ,Pešt'budínska kritika môže sa pod'akovat' svojmu , kniežat'u-básnikovi “ za onú utešenú charakteristiku. Iste len tam u nej mohol si nadobudnút' oných skúseností. Avšak vykrámit' to v prologu, pri slávnostnej príležitosti a pred kritikou, ktorú pozvali za host'a, je dôkazom len toho, že predsa ešte jestvujú naivni básnici. “' Chýrnik. In Národnie noviny, 29. 9. 1886, roč. 17, č. 144, s. 4. Ako autor prológu $\mathrm{k}$ otvoreniu nového divadla figuroval Jókai aj v prípade d’alších divadiel v Uhorsku, ako napr. v Arade, Temešvári, Fiume.

40 K posledným výskumom ku kompozičnej práci Ferenca Erkela pozri SZACSVAI-KIM, Katalin. Die Erkel-Werkstatt: Die Anfänge einer Arbeitsteilung in der Komposition. In Studia Musicologica, 2012, roč. 52, č. 4, s. 27-46. ISSN 1788-6244 a SZACSVAI-KIM, Katalin. Die erste ungarische Operntragödie: Ferenc Erkels Bátori Mária. Quellen und Fassungen. In Studia musicologica, 2015, roč. 55, č. 3, s. 1-58. ISSN 1788-6244.

41 Z listu adresovanému Ferencovi Erklovi intendantom Mad’arskej král'ovskej opery a Národného divadla Istvánom Keglevichom vyplýva, že účinkovanie budapeštianskych umelcov bolo chápané ako národná kultúrna misia. Intendant sa Erkela spýtal, či by bol ochotný účinkovat' na otváracom predstavení za podobných podmienok, pričom zdôraznil význam jeho prítomnosti v Prešporku. Skladatel' s návrhom súhlasil. Országos Széchényi Könyvtár, Kézirattár Fond XII/510, Keglevich István levelei Erkel Ferenchez, listy zo dňa 26. 8. 1886 a 28. 8. 1886. 
predstavení konali v novom divadle host'ujúce predstavenia ${ }^{42}$ Počas nasledujúcich štyroch dní boli uvedené mad'arské a inonárodné operné i činoherné predstavenia v mad'arčine, ktoré našli vel'ký ohlas u prešporského publika.

Hrdost' Prešporčanov na nové divadlo sa odzrkadl'ovala $\mathrm{v}$ početných správach uverejnených vo všetkých domácich denníkoch, a to nielen po skončení slávnostného večera, ale aj niekol'ko týždňov potom. Čo sa týka budapeštianskej alebo viedenskej tlače, rozsiahlejšia reflexia diania $\mathrm{v}$ prešporskom divadle v denníkoch hlavných miest sa krátko po slávnostnom otvorení skončila. Denná prevádzka „divadla v provincii“ totiž nebola pre obyvatel'ov hlavných miest zaujímavá. Pozorne ju ale sledovalo uhorské Ministerstvo vnútra a Krajinský uhorský divadelný spolok a dôchodkový ústav, ktorého členmi boli povinne všetci mad’arskí herci a speváci pôsobiaci v divadlách v provincii. ${ }^{43}$ Ministerstvo vnútra zároveň udel'ovalo divadelným riaditel'om, ktorí sa starali o nemecké predstavenia, licenciu a povolenie na pôsobenie v divadlách v rámci Uhorska.

$$
* * *
$$

Fakty o divadelnej novostavbe, podrobnosti z otváracieho večera a host'ovania v sebe ukrývajú tri skupinotvorné faktory, ktorými sa vyznačoval život Prešporčanov hovoriacich po nemecky na sklonku 19. storočia. Patril k nim sociálny status, uhorský patriotizmus a lokálna identita, hrdost'. Vybudovanie novej divadelnej budovy v roku 1886 symbolizovalo vzostup meštianskej vrstvy, ktorá s pomocou miestnej šl'achty dokázala zaplatit' stavbu divadla a tým potvrdila svoj sociálny status. Na priamu výzvu zo strany uhorskej vlády ohl'adom výstavby nového stánku Tálie odpovedali Prešporčania v duchu uhorského patriotizmu. Zadali zákazky umeleckým remeselníkom z Budapešti, vybrali mad’arských dramatikov do výklenkov na priečelí a na budovu umiestnili názov Városi színház. Ďalej pozvali umelcov z Budapešti na otváracie predstavenie a napokon rozhodli

42 BÉKÉSSY, Lili. A Nemzeti Színház ünnepei. Az intézmény és a Habsburg Dinasztia. In BARNA, Gábor - TAUPERT, Dóra (eds.). Emlékezö ritusok és ünneplés. Évfordulók, jubileumok, szent évek. Budapest: MTA-SZTE Vallási Kultúrakutató Csoport, 2018, s. 193.

43 Roku 1871 vzniklo Uhorské divadelné združenie (Magyar Színészkebelzet) na podporu záujmov mad'arského divadla. Patrili k nemu mad'arskí divadelní riaditelia a herci a v jeho kompetencii bolo vydávanie povolení na činnost' pre riaditel'ov a hercov v Uhorsku, ako aj organizovanie dôchodkového systému pre jeho členov. Roku 1873 sa zmenil názov na Uhorské združenie hercov (Magyar Színészek Egyesületére) a od roku 1878 združenie vystupovalo pod názvom Krajinský uhorský divadelný spolok a dôchodkový ústav (Országos Magyar Színészegyesület és Nyugdíjintézet). Od roku 1880 začalo platit' nariadenie, že každý herec pôsobiaci v divadle v provincii sa musel stat' členom združenia, $\mathrm{v}$ opačnom prípade ho žiaden riaditel' nezamestnal. SZÉKELY, György (ed.). Magyar színházmüvészeti lexikon [online]. Budapest: Akadémiai Kiadó, 1994. Dostupné na internete: <http://mek.niif.hu/02100/02139/ html/sz18/76.html>. [cit. 2019-26-01]. 
o rozdelení sezóny na nemeckú a mad'arskú čast's predstaveniami v príslušnom jazyku. ${ }^{44}$

Posledným faktorom bola lokálna identita, ktorá sa prejavila jednak v postavení novej dôstojnej divadelnej budovy, ale hlavne v každodennej návšteve predstavení (predovšetkým) počas nemeckej časti sezóny. Podpora divadelného riaditel'a stelesňovala kultúrnost' mesta a jeho obyvatel'ov a naopak. Patrila k nej aj hrdost' na rozhodovanie o veciach mesta $\mathrm{v}$ rámci municipálneho výboru. Tu $\mathrm{s}$ postupujúcou mad'arizáciou prichádzalo $\mathrm{k}$ problémom, pretože o divadelnej budove ako majetku mesta mali rozhodovat' členovia municipálneho výboru. Uhorská vláda však zasahovala do rozhodnutí pozdržaním povolenia pre nemecké predstavenia, príp. neschválením vybraného divadelného riaditel'a. Ciel’om nového divadla malo byt' sprostredkovanie klasického vzdelania obyvatel'om Prešporka a zabezpečenie zábavy na dobrej úrovni. Uhorská vláda videla v divadle nástroj na presadzovanie politických ideí. Pri dostavbe novej budovy sa spomínala možnost' pomenovat' novopostavené divadlo za národné, čo by pre Prešporok znamenalo vel'kú poctu a zaradenie sa k významným mestám v strednej Európe. Prešporčania však nemali záujem o „zmenu mena“, ale o reálnu podporu zo strany uhorskej vlády. Svoje divadlo pomenovali ako mestské, pričom v ňom poskytli priestor pre národné (mad’arské) predstavenia. Prelínanie zábavy a politiky bolo typické pre divadlá v 19. storočí, Prešporok netvoril výnimku. Špecifický bol spôsob, akým k tomu dochádzalo, a to práve vd’aka uvedeným skupinotvorným faktorom.

Pri pohl'ade na d’alší vývoj Mestského divadla možno konštatovat', že divadlo ako dynamický systém v sebe ukrýva príbeh s dôležitými konfliktmi, kontroverziami a porážkami. Preto nie je možné o ňom napísat' rýdzo „úspešnú story“, ale je potrebné poukázat' na interné (a zároveň heterogénne) boje o moc s politickými a ekonomickými zásahmi, z ktorých vzišli vít’azi i porazení. Reprezentácia a inscenácia - aj takto možno pomenovat’ javy, ktoré vplývali na vývoj mestských divadiel v 19. storočí. Ich odkrývanie sa prelína s výskumom kultúrnych dejín mesta, dejín mentalít a kolektívnych identít jeho obyvatel'ov, pričom „lokálne“ sa posúva do roviny „translokálne“. Predkladaná štúdia priblížila vznik

44 O rozdelení sezóny na dve časti sa rokovalo od začiatku stavby, pretože jeden z argumentov, ktorý rozhodol v prospech postavenia nového divadla, bol vytvorit' stabilné miesto pre mad'arské divadlo. V priebehu rokov 1884 - 1886 mesto poverilo divadelnú komisiu preskúmaním možnosti získania štátnej subvencie od uhorskej vlády, ked’že sa vedelo, kto tvoril divadelné publikum v Prešporku. Zároveň komisia prizvala zástupcov významných mestských spolkov, aby sa vyjadrili k návrhu prenajat' divadlo mad'arskému riaditel'ovi. Po obdržaní zamietavej odpovede $\mathrm{z}$ Budapešti komisia predložila municipálnemu výboru návrh na striedanie sa nemeckej a mad'arskej sezóny v divadle v zmysle dualizmu krajiny. AMB, Magistrát mesta Bratislavy, Mestské zariadenia XI/5 - Divadlo, úradné knihy, zápisnice zo zasadnutí divadelnej komisie z rokov 1881 - 1885, k. 2d 6/2, inv. č. 15861. 
Mestského divadla v Prešporku na sklonku 19. storočia v korelácii kultúrnych dejín mesta. Postavenie nového divadla úzko súviselo so snahou obnovit' kultúrnu pamät' mesta a sprítomnit' jeho bohatú minulost' prostredníctvom nového média kultúrneho transferu, o čom svedčí aj ponímanie divadla ako centrálnej umeleckej inštitúcie zo strany mesta a jeho obyvatel'ov. Prevádzkový model Mestského divadla, ako aj sociálne kontexty a štruktúry, ktoré ho na sklonku 19. storočia determinovali, spoluvytvárali jeho obraz a podiel'ali sa na konštruovaní jeho hodnoty. Prítomnost' jazykovej rozmanitosti zastúpená divadelnými riaditel'mi a členmi ich spoločností prichádzajúcich do Prešporka, ako aj skutočnost' častej migrácie účinkujúcich, viedla k siet'ovaniu mestských divadiel v rámci stredoeurópskeho priestoru. Hl'adanie príbuzných prvkov v uvádzanom repertoári poukazuje na kultúrnu transláciu a cirkuláciu v danom prostredí a verifikuje špecifické postavenie prešporského Mestského divadla vo vývoji mestských divadiel v strednej Európe v 19. storočí. ${ }^{45}$

* Táto štúdia vznikla v rámci projektu VEGA: Hudobné divadlo v Bratislave od druhej polovice 19. do prvej polovice 20. storočia (osobnosti, inštitúcie, repertoár, reflexia), riešeného na Historickom ústave a bola podporená Agentúrou pre vedu a výskum v rámci projektu APVV-14-0681: Hudba v Bratislave, riešeného na Katedre muzikológie Filozofickej katedry UK v Bratislave.

\section{DAS PRESSBURGER STADTTHEATER IM KONTEXT DER ENTWICKLUNG DER STADTTHEATER IN MITTELEUROPA IN DER ZWEITEN HÄLFTE DES 19. JAHRHUNDERTS}

\section{JANA L A S L A V Í K O V Á}

Am 22. September 1886 fand die feierliche Eröffnung des neuen Stadttheaters in Pressburg ( heute Historisches Gebäude des Slowakischen Nationaltheaters in Bratislava) statt, dessen Autoren, Ferdinand Fellner der Jüngere und Hermann Gottfried Helmer, zu den bekanntesten Theaterarchitekten der damaligen Österreichischen-Ungarischen Monarchie gehörten. Das neue Theatergebäude veränderte das Gesicht der Stadt und trug zur Repräsentation sowie zum Prestige von Pressburg und Bewohnern der Monarchie bei, da der Besuch der Theateraufführungen zu untrennbarem Bestandteil des gesellschaftlichen Lebens der Pressburger Einwohnern gehörte und den Rahmen der kollektiven Repräsentation darstellte. Zugleich handelte es sich hierbei um ein der ersten

45 Pozri viacej MÜLLER-FUNK, Wolfgang - PLENER, Peter - RUTHNER, Clemens. Kakanien revisited: das Eigene und das Fremde (in) der österreichisch-ungarischen Monarchie. Tübingen; Basel: A. Francke Verlag, 2002. ISBN 9783772032103. 
Projekte der beiden Wiener Architekten nach Einführung neuer Sicherheitsvorschriften für Theaterbauten, das die Ergebnisse der praktischen Anwendung dieser Vorschriften darstellte und als Ausgangspunkt für weitere Bauwerke galt.

Dramatische Kunst gewann mit dem neuen Gebäude nicht nur ein neues Zuhause, sondern auch ein neuen Status und mit ihm auch eine neue Berufung. Dem geplanten Zweck nach sollte das neue Theaters als Ort der Pflege der ungarischen Kultur dienen, doch angesichts der überwiegenden deutschsprachigen Bevölkerung in der Zeit des Gebäudeaufbaus war es ersichtlich, dass ausschließlich ungarische Aufführungen unrentabel wären. Auch der städtische Ausschuss betrachtete dies mit Rücksicht auf kulturelle Präferenzen des Stammpublikums als inakzeptabel. Aufgrund dessen beschloss die Stadt die Abwechslung der deutschen und der ungarischen Theateraufführungen im Stadttheater, wobei diese Lösung als vorübergehend präsentiert wurde.

Das auf der Abwechslung der Leiter der deutschen und der ungarischen Aufführungen beruhende Betriebsmodell der Stadttheater und die daraus rührende häufige Migration der Akteure wie auch die kulturelle Übertragung und ein zirkulierendes Theaterrepertoire prägten das Bild des Pressburger Theaterlebens am Ende des 19. Jahrhundert und trugen zu seinem Wertaufbau bei.

Mgr. Jana Laslavíková, PhD.

Historický ústav SAV

Klemensova 19, 81499 Bratislava

jana.laslavikova@savba.sk 


\section{Štefan Gaučík Mestské múzeum v Prešporku $\mathrm{v}$ kontexte doby $(1868-1918)$}

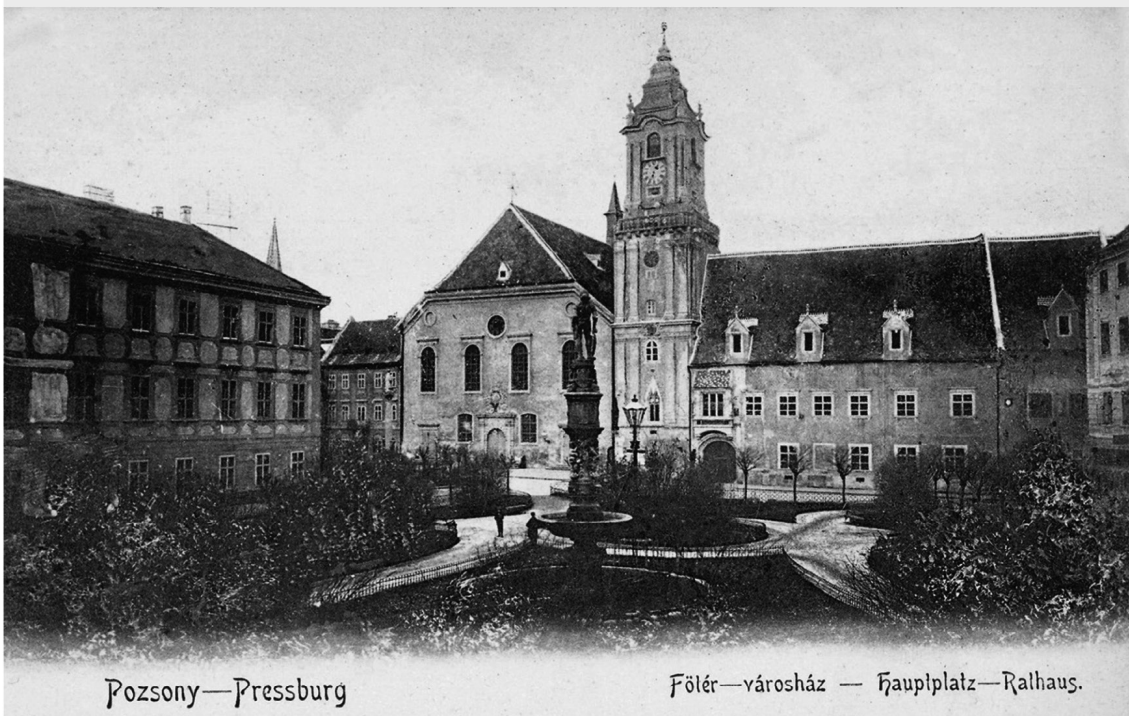

Historický ústav Slovenskej akadémie vied Veda, vydavatel'stvo Slovenskej akadémie vied 